\title{
ANALISA KEBIJAKAN PEMERINTAH KOTA KEDIRI DALAM PENINGKATAN DAYA SAING SUMBER DAYA MANUSIA (SDM) DI DUNIA INTERNASIONAL
}

\author{
ANALYSE OF LOCAL GOVERNMENT ROLES TO IMPROVING \\ HUMAN RESOURCES (HR) COMPETITIVENESS ON THE WORLD \\ (Case Study on Kediri City) \\ Yudiyanto Tri Kurniawan \\ Badan Penelitian dan Pengembangan Provinsi Jawa Timur \\ Yudi.balitbang@gmail.com
}

\begin{abstract}
ABSTRAK
Pertimbangan komposisi ketenagakerjaan Indonesia saat ini dan menghadapi tantangan persaingan global menyongsong perdagangan bebas maka kami akan menganalisa kebijakan Pemerintah Daerah dalam peningkatan Daya Saing Sumber Daya Manusia (SDM) di dunia internasional, yang mengambil studi kasus di Kota Kediri. Penelitian ini merupakan penelitian Kualitatif Deskriptif dengan teknik Studi kasus. Pengumpulan data dilakukan dengan teknik wawancara mendalam, obsevasi lapangan dan dokumentasi. Informasi yang diperoleh diolah melalui proses kondensasi data dan dianalisa dengan Faktor kesiapan dari IMD World Talent Ranking. Dari hasil penelitian diketahui Kebijakan Pemerintah daerah dalam meningkatkan Daya Saing Sumber Daya Manusia (SDM) di Kota Kediri relatif banyak, beragam dan dilaksanakan oleh banyak Satuan Kerja Pemerintah Daerah (SKPD) yang dimiliki baik Pemerintah Provinsi maupun Pemerintah Kota. Serta Secara rerata kebijakan-kebijakan tersebut akan relatif berdampak positif terhadap peningkatan Daya Saing SDM di dunia internasional.
\end{abstract}

Kata Kunci : Kebijakan Pemerintah Daerah, Daya saing, Sumberdaya Manusia, Dunia Internasional.

\section{ABSTRAC}

Consideration of the composition of employment Indonesia today and face the challenges of free trade to meet the global competition we will analyze regional government policy in improving the Competitiveness of Human Resources (HR) in the international community, which is a case study in Kediri. This research is qualitative descriptive with case study technique. The data collection was done by using in-depth interviews, field observation and documentation. The informations processed by data condensation and analized by readiness factor of IMD Worid Talent Ranking. The results show government policies in improving Competitiveness Human Resources (HR) Kediri relatively plentiful, varied and implemented by many Local Government Unit (LGU) owned both the Provincial Government and the City Government. In the mean as well as those policies will have a positive impact relative to the increase of Competitiveness human resources in the international world.

Keyword : Local Government Policy, Competitiveness, Human Resources, International World. 


\section{PENDAHULUAN}

Secara kuantitas Indonesia memiliki Sumber Daya Manusia (SDM) yang relatif besar $43 \%$ dari total seluruh penduduk Asia Tenggara dan peringkat ke 5 terbesar di dunia. Jumlah tersebut dapat menjadi modal yang baik dalam persaingan dunia, namun dapat juga menjadi beban negara jika tidak terkelola dengan baik. Pemerintah menetapkan Rencana Pembangunan Jangka Menengah Nasional ke 3 tahun 2015-2019 dengan menitik beratkan pada memantapkan pembangunan secara menyeluruh di berbagai bidang dengan menekankan pencapaian daya saing kompetitif perekonomian berlandaskan keunggulan sumber daya alam dan sumber daya manusia berkualitas serta kemampuan IPTEK yang terus meningkat.

Pemerintah menetapkan 9 agenda prioritas untuk mencapainya, yang diantaranya adalah akan meningkatkan produktivitas rakyat dan daya saing di pasar internasional. SDM Indonesia harus mampu bersaing dengan negara lain, keja sama pemerintah, swasta dan masyarakat umum diharapkan mampu menciptakan tenaga kerja Indonesia yang terampil.

Pengembangan SDM tidaklah semudah membalikkan telapak tangan mengingat jumlah penduduk Indonesia saat ini lebih dari 250 juta jiwa. Sedangkan pada Agustus 2015 Kondisi angkatan kerja Indonesia sebanyak 122,4 juta orang, Penduduk bekerja sebanyak 114,8 juta orang. Tingkat Pengangguran Terbuka (TPT) sebesar 6,18 persen, penduduk bekerja masih didominasi oleh mereka yang berpendidikan SD ke bawah sebesar 44,27 persen, sementara penduduk bekerja dengan pendidikan Sarjana ke atas hanya sebesar 8,33 persen.

Dan untuk Jawa Timur sendiri Tingkat Pengangguran Terbuka (TPT) Februari 2015 sebesar 4,31 persen. TPT tertinggi adalah Kota Kediri yang mencapai 8,46 \% . Kota Kediri tercatat 11.133 jiwa pengangguran terbuka dari 145.426 jiwa angkatan kerja. Data tersebut mengacu pada Survei Angkatan Kerja Nasional (Sakernas) pada bulan Agustus 2014.

Berdasarkan gambaran awal kondisi ketenagakerjaan di wilayah kota Kediri tersebut dan tantangan masa Masyarakat Ekonomi ASEAN (MEA) yang telah dimulai pada tahun 2015 dan menyongsong Perdagangan bebas Asia pada tahun 2020 maka kami dari akan menganalisa kebijakan Pemerintah Daerah dalam peningkatan Daya Saing Sumber Daya Manusia (SDM) di dunia internasional, yang mengambil studi kasus di Kota Kediri.

\section{RUMUSAN MASALAH}

1. Apa saja kebijakan Pemerintah daerah dalam meningkatkan Daya Saing Sumber Daya Manusia (SDM) di Kota Kediri ?

2. Bagaimana dampak kebijakan Pemerintah daerah tersebut terhadap peningkatan Daya Saing Sumber Daya Manusia (SDM) di Kota Kediri?

\section{METODE PENELITIAN}

Penelitian ini merupakan penelitian Kualitatif Deskriptif dengan teknik Studi kasus. Pengumpulan data dilakukan dengan teknik :

1. Wawancara mendalam (Deep Interview) untuk memperoleh Data Primer

2. Observasi lapangan, untuk mengetahui kondisi lapangan.

3. Dokumentasi, dengan data Sekunder, didapatkan dari:

a) Data statistik dari Kantor BPS Kota Kediri,

b) Data Pendukung/Pelengkap dari Kantor Pemeritah Kota kediri terkait, serta

c) Data-data pendukung lainnya dari website/internet. 
Sedangkan untuk mendapatkan informasi semaksimal mungkin disini kami menggunakan Metode Pengambilan Sample informan dengan metode Purposive, yaitu beberapa orang pejabat di lingkup pemerintah kota Kediri, dengan key informan adalah pejabat di Badan Perencanaan Pembangunan Daerah (BAPPEDA) Kota Kediri.

Informasi yang diperoleh diolah melalui proses kondensasi data (Milles \& Huberman: 2012), selanjutnya untuk menganalisa pengaruh kebijakan-kebijakan tersebut terhadap competitiness dengan Faktor kesiapan (Readiness Factor pada Struktur dari IMD World Talent Ranking) tenaga kerja terdiri dari 12 unsur.

\section{HASIL PENELITIAN DAN PEMBAHASAN}

Kota Kediri memiliki luas wilayah $63,40 \mathrm{~km}^{2}$ dan terletak antara $07^{\circ} 45^{\prime}-07^{\circ} 55^{\prime} \mathrm{LS}$ dan $111^{\circ} 05^{\prime}$ $112^{\circ} 3^{\prime} \mathrm{BT} \cdot{ }^{[6]}$ Dari aspek topografi, Kota Kediri terletak pada ketinggian rata-rata 67 meter di atas permukaan laut, dengan tingkat kemiringan 0-40\%, jumlah penduduk Kota Kediri pada tahun 2014 293.282 jiwa, Kepadatan penduduk sebesar 4.626 jiwa per km² (Statistika Kota Kediri 2015).

Pada diagram dibawah ini menunjukkan PDRB Perkapita Atas Dasar Harga Berlaku (ADHB) Kabupaten/Kota di Jawa Timur tahun 2010, Kota Kediri memegang urutan nomor satu. yang menunjukkan jika Kota Kediri memiliki kemampuan ekonomi terbaik.

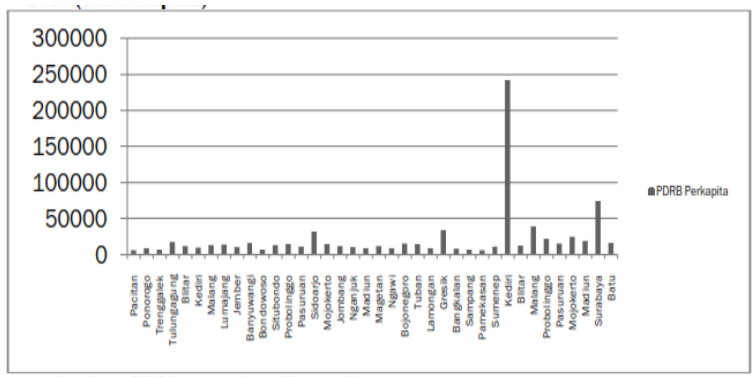

Gambar 1. Grafik PDRB Perkapita Atas Dasar Harga Berlaku (ADHB) Kabupaten/Kota di Jawa Timur tahun 2010.

Tingginya kemampuan ekonomi tersebut tidak menjamin tersedianya lapangan kerja yang cukup untuk penduduknya. Tingkat Pengangguran Terbuka Kota Kediri tahun 2006 - 2011 dalam Persen (\%) seperti tampak pada diagram dibawah ini.

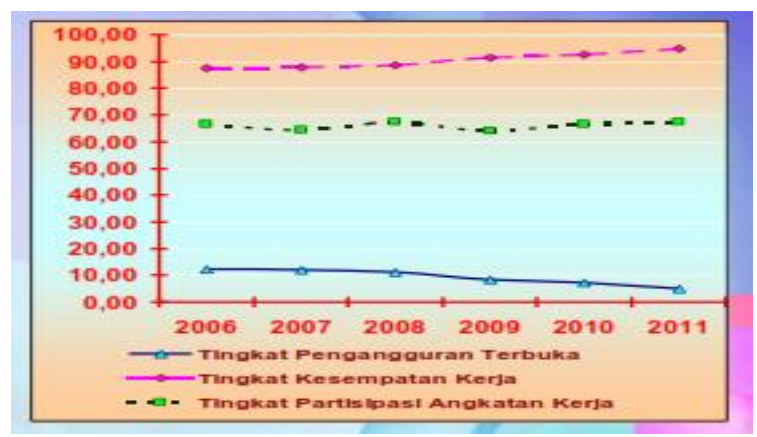

Gambar 2. Tingkat Pengangguran Terbuka, Tingkat Kesempatan Kerja dan Tingkat Partisipasi Angkatan Kerja Kota Kediri tahun 2006 - 2011 dalam Persen (\%).

Potensi SDM tersebut jika siap bersaing pada persainangan global akan memberikan peluang untuk menurunkan angka TPT karena peluang bekerja di negara lain akan terbuka lebar. Namun jika SDM yang kita miliki tidak siap bersaing dengan SDM dari negara lain maka malahan akan 
meningkatkan TPT negara kita karena SDM kita tersisih di dalam persaingan dengan SDM negara lain.

Disinilah pentingnya peran pemerintah saat ini, pemerintah harus mampu meningkatkan daya saing dari SDM kita. Bagi yang masih bekerja baik di sektor formal maupun informal harus didongkrak kapabilitas, kapasitas dan produktivitasnya untuk tetap survive pada persaingan dengan SDM negara lain. Sedangkan untuk yang belum bekerja dan termasuk dalam TPT pemerintah sangat urgent untuk memikirkan jalan keluar bagi mereka.

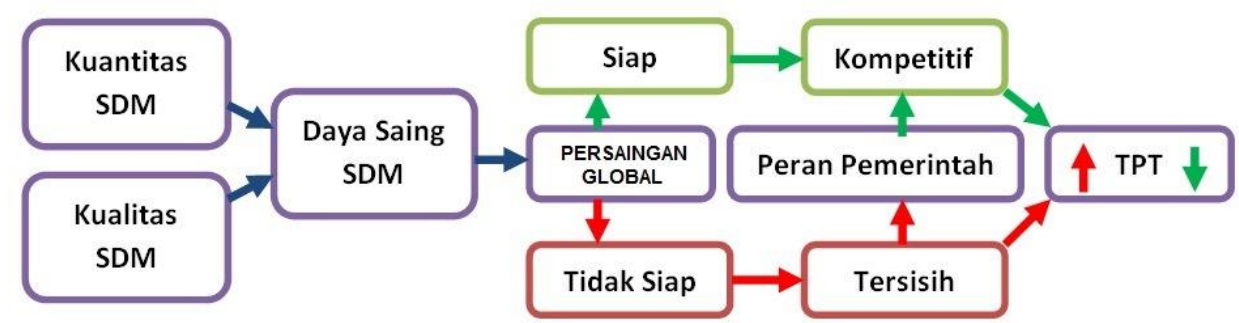

Gambar 3. Kerangka Konsep Peran pemerintah daerah dalam meningkatkan daya saing sumber daya manusia (SDM) di kota kediri dalam menghadapi persaingan global.

\section{KEBIJAKAN PEMERINTAH DAERAH DALAM PENINGKATAN DAYA SAING SDM DI KOTA KEDIRI}

Liberalisasi perdagangan akan menyebabkan persaingan di pasar global, diantaranya adalah masuknya tenaga kerja dari luar negeri. Sehingga Pemerintah Kota Kediri harus menyiapkan sumber daya manusia yang mampu memanfaatkan dan memiliki daya saing tinggi agar dapat menembus persaingan global. Langkah Strategis yang dilakukan Pemerintah Kota Kediri antara lain :

\section{Sosialisasi Kepada Masyarakat Luas .}

Agar masyarakat memiliki kesiapan sehingga mampu menumbuhkan rasa percaya diri untuk memanfaatkan peluang dan meningkatkan daya saing dan mampu menembus pasar luar negeri.

Kegiatan Sosialisasi dilakukan dengan memanfaatkan media informasi yang dikelola oleh Bagian Humas dan protokol melalui :

- Website www.kediri.go.id

- Surga (Suara Warga), sebagai media aduan masyarakat.

- Media cetak dan sosial media yaitu melalui tabloid Kota Kita (terbit 1 bulan sekali), Majalah Barometer (terbit 3 bulan sekali), Radio Barometer dan Facebook Harmoni Kota Kediri dan Barometer FM.

- Bakdrop/spanduk kegiatan-kegiatan.

Dan pada tahun 2016 dalam direncanakan kegiatan memberikan informasi kepada masyarakat dalam menyambut MEA untuk pembinaan dan pengembangan jaringan komunikasi dan informasi, serta pembinaan dan pengembangan Sumber Daya Komunikasi dan informasi.

\section{Meningkatkan Kompetensi dan kualifikasi tenaga kerja agar mampu membuka lapangan usaha} mandiri serta mampu bersaing dalam mengisi lapangan kerja yang tersedia.

Kegiatan peningkatan dan perlindungan tenaga kerja dilakukan melalui program Dinsosnaker, antara lain :

- Pendidikan dan pelatihan bagi pencari kerja guna mempersiapkan tenaga kerja yang siap pakai, 
- Penyebarluasan informasi bursa tenaga kerja,

- Penyiapan tenaga kerja siap pakai, pengembangan kelembagaan produktifitas dan pelatihan kewirausahaan,

- Memberikan pembekalan bagi pekerja pada jabatan-jabatan sesuai MRA (Mutual Reconition Arrangement) untuk : enginnering pada bidang usaha konstruksi/jasa/industri, Arsitek pada bidang usaha konstruksi/bangunan, tenaga survey pada bidang surveyor, peranan pada bidang kesehatan, akuntan pada bidang keuangan dan tenaga pariwisata pada bidang perhotelan. Hasil akhirnya diperolehnya sertifikasi kompetensi pada jabatan-jabatan tersebut.

Dan selanjutnya pada rencana program kegiatan pemerintah Kota Kediri tahun anggaran 2016 Dinsosnaker mendapatkan anggaran untuk program-program kegiatan diantaranya yaitu :

- Program Peningkatan kualitas dan produktifitas tenaga kerja dengan target 40 orang pencari kerja dengan tujuan meningkatkan daya saing dan kompetensi/ketrampilan calon tenaga kerja.

- Program peningkatan kesempatan kerja dengan kegiatan penyiapan tenaga kerja siap pakai dan bertujuan untuk penyerapan tenaga kerja sampai lulus uji kompetensi.

- Program peningkatan kesempatan kerja dengan kegiatan pengembangan kelembagaan produktifitas dan pelatihan kewirausahaan untuk peningkatan manajemen kewirausahaan baru .

- Program pembinaan lingkungan sosial dengan kegiatan pembinaan kemampuan dan ketrampilan kerja masyarakat di lingkungan industri hasil tembakau untuk meningkatkan ketrampilan pencari kerja.

\section{Memberikan pelatihan agar masyarakat melek iptek dan mengembangkan potensinya.}

Kegiatan dilakukan melalui Dinas Perhubungan, Komunikasi dan Informatika, antara lain :

- Memberikan pelatihan e-commerce kepada Kelompok Informasi Masyarakat (KIM) berupa : cara membuat blog dan menggunakan sosial media sebagai sarana pemasaran.

- Sarasehan Teknologi Informasi dengan topik Internet Marketing, kepada komunitas IT Kediri, mahasiswa dan masyarakat umum.

- Pelatihan IT untuk karang taruna, ibu-ibu PKK dan pengurus LPMK. Untuk karang taruna materinya Desain Grafis. Diharapkan peserta memiliki ketrampilan untuk membuat poster, sepanduk, sablon kaos layout majalah, koran. Ibu-ibu juga dilatih untuk bisa mencari informasi di internet dan memanfaatkan sosial media. Pengurus LPMK dilatih untuk mencari inormasi di internet, membuat surat dan perhitungan.

- Lomba IT

- Sosialisasi UU Nomor 11 tahun 2008 tentang Informasi dan Transaksi Elektronik, yang menjadi bekal para pelaku usaha pengguna dunia maya agar memahami aturan main serta keamanan dan ancaman dalam melakukan transaksi elektronik.

- Disediakan sarana publikasi dan pembinaan berupa lomba Kelompok Informasi Masyarakat (KIM) dan Pertunjukan Rakyat (PERTURA).

\section{Meningkatkan Kemampuan masyarakat dalam Berbahasa Asing.}

Melalui program "English Massive Program (EMAS)" oleh Dinas Pendidikan. Pelatihan bahasa inggris berbasis massa yang dilaksanakan secara gratis. Masyarakat secara gratis akan mendapatkan pelatihan bahasa inggris di tingkat RT dengan asisten tutor terpilih yang telah 
dibina secara khusus dibawah Dinas Pendidikan Kota Kediri. Tahun 2015 pada tahap pelatihan Tutor sedangkan taahun 2016 diprogramkan untuk implementasi English Massie di seluruh RT di wilayah Kota Kediri.

Dan selanjutnya pada rencana program kegiatan pemerintah Kota Kediri tahun anggaran 2016 Dinas Pendidikan mendapatkan anggaran untuk program Manajemen Pelayanan Pendidikan dalam bentuk kegiatan penyelenggaraan pelatihan, seminar dan lokakarya serta diskusi ilmiah tentang berbagai isu pendidikan dengan tujuan meningkatkan kualitas masyarakat (bahasa Inggris).

Selain itu pemerintah kota Kediri juga menggulirkan program seragam gratis bus sekolah gratis untuk pelajar mulai tingkat sekolah dasar hingga sekolah menengah atas, program beasiswa dan pada tahun 2016 sempat akan memberikan lembar kerja evaluasi belajar siswa SD sebagai pengganti LKS, namun dibatalkan karena permasalahan payung hukumnya.

5. Meningkatkan diversifikasi usaha, kualitas produk dan perlindungan terhadap pelaku usaha lokal

Program dan kegiatan yang dilaksanakan melalui Dinas Koperasi dan UMKM terkait peningkatan daya saing SDM diantaranya yaitu :

- Pelatihan-pelatihan, shortcourse konveksi dan hidroponik.

- Penyelenggaraan Pelatihan kewirausahaan, pelatihan Packaging dan pelatihan pemasaran online, serta Sosialisasi HAKI

- Pelatihan peningkatan SDM pengelolaan dana bergulir, meningkatkan SDM pengelola dana bergulir dalam mendukung koperasi dan UMKM mengakses pembiayaan.

- Pelatihan servis HP, menyiapkan kader-kader wirausaha muda agar siap bersaing dalam berwirausaha, membuka lapangan pekerjaan maupun menjadi tenaga terdidik dan terlatih.

Dan selanjutnya pada rencana program kegiatan pemerintah Kota Kediri tahun anggaran 2016 Dinas Koperasi dan UMKM mendapatkan anggaran untuk program-program kegiatan diantaranya yaitu Program pengembangan kewirausahaan dan keunggulan kopetitif usaha kecil menengah melalui kegiatan penyelenggaraan pelatihan kewirausahaan, serta kegiatan pendidikan/pelatihan bagi masyarakat calon wirausaha baru yang bertujuan menyiapkan kaderkader wirausaha muda agar siap bersaing dalam berwirausaha, membuka lapangan pekerjaan maupun menjadi tenaga pendidik dan terlatih.

\section{Pelestarian dan Pengembangan Budaya Lokal serta aktualisasi potensi kepemudaan.}

Dampak negatif dari globalisasi adalah lunturnya nilai-nilai budaya luhur bangsa. Untuk membentengi serta meningkatkan rasa cinta masyarakat terhadap budaya daerah yang telah berkembang baik, ditanamkan rasa cinta pada budaya luhur daerah dengan menggerakkan potensi seni dan budaya daerah dan potensi kepemudaan agar dapat memperkuat perekonomiaan daerah, melalui Disbudparpora, Bentuk kegiatannya yang terkait peningkatan daya saing SDM diantaranya yaitu :

- Pelatihan duta-duta pariwisata dan promosi pariwisata (kediri Carnival).

- Melakukan pembinaan dan pelatihan kepada para pemuda dibidang kewirausahaan.

7. Peningkatan mutu sarana dan prasarana pelayanan kesehatan, standarisasi mutu layanan dan standarisasi profesi tenaga kesehatan.

Dai tahun 2016 Dinas Kesehatan Kota Kediri memberikan dukungan dalam hal peningkatan Sarana Prasarana dan SDM Tenaga Kesehatan serta mutu dan pelayanan di Puskesmas dan Puskesmas Pembantu. Bentuk dukungan diantaranya yaitu dalam bentuk dukungan peningkatan 
mutu SDM melalui kemitraan peningkatan kualitas dokter dan paramedis, dengan melaksanakan Diklat dan pelatihan pengembangan kapasitas tenaga kesehatan diantaranya pembinaan tenaga Fungsional di Puskesmas (Medis dan Paramedis).

\section{ANALISA DAYA SAING SUMBER DAYA MANUSIA (SDM) DI KOTA KEDIRI}

Hasil penelitiannya berjudul IMD World Talent Report 2015 yang menghasilkan peringkat tenaga berbakat dan terampil di dunia, yang bertujuan untuk menilai sejauh mana negara tersebut menarik dan mampu mempertahankan tenaga berbakat dan terampil yang tersedia di negaranya untuk ikut berpartisipasi dalam perekonomian di suatu negara. Peringkat Indonesia turun 16 peringkat dari peringkat ke-25 pada tahun 2014 menjadi peringkat ke-41 pada tahun 2015.

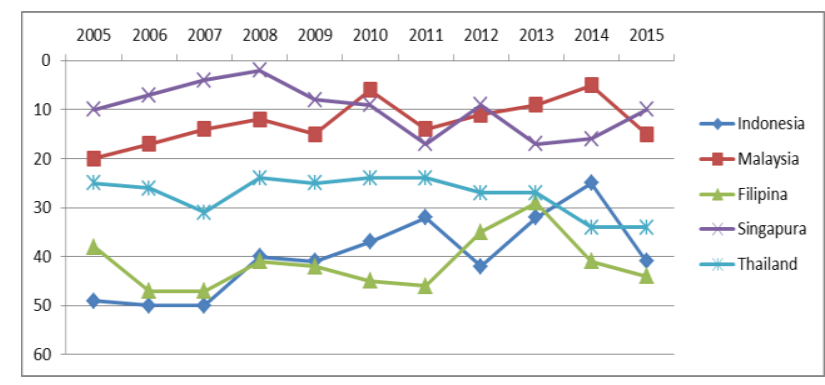

Gambar 4. Perkembangan Rangking 5 negara ASEAN pada IMD World Talent Report

Posisi Indonesia berada jauh di bawah posisi negara tetangga seperti Singapura, Malaysia, bahkan Thailand. Posisi Indonesia juga hanya sedikit lebih baik dari Filipina. Peringkat ini dihitung dengan bobot tertentu dengan mempertimbangkan tiga faktor yaitu faktor pengembangan dan investasi, faktor daya tarik suatu negara, dan faktor kesiapan sumber daya manusia. Masing masing faktor terbagi lagi ke dalam beberapa rincian lainnya.

Dua faktor pertama Indonesia mempunyai peringkat yang relatif sama dengan tahun sebelumnya. Akan tetapi untuk faktor ketiga yaitu kesiapan sumber daya manusia merupakan hal yang paling dominan menyumbang angka penurunan peringkat tenaga terampil Indonesia di tahun 2015 yaitu peringkat 42, padahal pada tahun 2014 masih peringkat ke-19. Berikut perkembangan rangking dari 12 unsur kesiapan SDM Indonesia tahun 2014 - 2015.

\begin{tabular}{|c|c|c|c|}
\hline \multirow{2}{*}{ NO } & \multirow{2}{*}{ FAKTOR } & \multicolumn{2}{|c|}{ PERINGKAT IMD } \\
\hline & & 2014 & 2015 \\
\hline 1 & Pertumbuhan tenaga kerja (Labor force growth) & 43 & 5 \\
\hline 2 & Tenaga KerjaT Terampil (Skilled' Labor) & 14 & 39 \\
\hline 3 & Ketrampilan Keuangan (Finance skills) & 34 & 44 \\
\hline 4 & Pengalaman Internasional (International experience) & 13 & 29 \\
\hline 5 & Manajer senior berkompeten (Competent senior monagers) & 15 & 38 \\
\hline 6 & Sistem Pendidikan (Educational system) & 20 & 39 \\
\hline 7 & IImu Pengetahuan di Sekolah (Soience in schools) & 15 & 39 \\
\hline 8 & Pendidikan Universitas (University education) & 20 & 33 \\
\hline 9 & Pendidikan Manajemen (Monagement education) & 26 & 31 \\
\hline 10 & Ketrampilan Bahasa (Lanquage skil/s) & 23 & 38 \\
\hline 11 & Mabilitas Ikatan Pelajar (Student mobility inbound) & - & 57 \\
\hline 12 & Kaijan Pendidikan (Educational assessment - PISA) & - & 54 \\
\hline
\end{tabular}

Gambar 5. Perkembangan Rangking Indonesia pada IMD World Talent Report

Dari berbagai Program dan kegiatan yang telah dilaksanakan pada kurun tahun 2015 dan yang diprogramkan pada tahun 2016 tersebut sudah cukup banyak dan diharapkan dapat meningkatkan kompetitifness SDM dalam menghadapi persaingan di Kota Kediri. Hasil analisa program-program tersebut, antara lain : 
1) Pertumbuhan tenaga kerja (Labor force growth), yaitu persentase perubahan jumlah tenaga kerja (Percentage change in labor force),

Pertumbuhan tenaga kerja di Kediri relatif tinggi, sehingga dapat menjadi keunggulan kuantitatif pada kompetisi ketenagakerjaan. Namun kwantitas tersebut juga berpotensi negatif jika secara kualitas SDM tersebut rendah.

Disinilah sangat pentingnya peran pemerintah daerah untuk merubah potensi tersebut menjadi keunggulan yang nyata dalam bentuk produktifitas yang berdaya saing global. Pemerintah perlu untuk update secara berkala dan kontinyu data tenaga kerja beserta potensi yang dimilikinya sehingga dapat memberikan support dan fasilitasi sesuai kebutuhan untuk pengembangan potensinya tersebut. Disisi lain dapat meningkatkan efektifitas dan efisiensi dari program kegiatan peningkatan daya saing SDM.

2) Tenaga Kerja Terampil (Skilled Labor), yaitu Hasil Survey tenaga kerja terampil yang siap dimanfaatkan di lapangan kerja (Skilled labor is readily available).

Untuk itu pada tahun 2015 Pemerintah Kota Kediri telah melaksanakan berbagai program kegiatan melalui beberapa SKPD yang dimilikinya dan pada tahun 2016 telah memprogramkan beberapa kegiatan lainnya. Secara garis besar program-program tersebut akan relatif meningkatkan kompetitifness SDM di Kota Kediri.

Namun berdasarkan informasi dari hasil wawancara mendalam (indept interiew) beberapa informan diketahui ada beberapa kendala yang ditemukan pada pelaksanaa program-program peningkatan SDM tersebut, diantaranya :

- Keterbatasan anggaran sehingga cakupan penerima manfaat relatif kecil.

- Belum adanya integrasi dan sinkronisasi data penerima manfaat dari SKPD-SKPD pelaksana program, berpotensi mengurangi efektifitas dan efisiensi,

- Need to Achievement (Keinginan untuk berprestasi) dari masyarakat Kota Kediri relatif rendah karena telah lama merasakan kemapanan dari hasil SDA dan Industri.

- Belum adanya kesadaran masyarakat di Kota Kediri akan ancaman persaingan global karena belum merasakan dampaknya secara langsung, meskipun Pemkot telah melaksanakan sosialisasi.

3) Ketrampilan Keuangan (Finance skills), yaitu Hasil Survey ketrampilan/keahlian dalam bidang keuangan yang siap dimanfaatkan di lapangan kerja (Finance skills are readily available )

Pada tahun 2015 Pemerintah Kota Kediri telah melaksanakan beberapa program kegiatan melalui beberapa SKPD yang dimilikinya dan pada tahun 2016 telah memprogramkan beberapa kegiatan lainnya. Diantaranya:

- Pelatihan Kewirausahaan yang didalamnya dibekali juga peningkatan ketrampilan finansial.

- Pembekalan bagi pekerja pada jabatan sesuai MRA (Mutual Recognition Arrangement) diantaranya akuntansi pada bidang keuangan dan hasinya akan diberikan sertifikat kompetensi.

- Untuk pelaku UMKM diberikan peningkatan ketrampilan financial dalam bentuk pengelolaan dana bergulir.

- Sistem pendidikan kita sudah ada muatan pendidikan ekonomi mulai SLTP hingga perguruan tinggi, berupa ketrampilan akuntansi, bahkan sudah ada pendidikan yang khusus bidang ini. 
Namun dari informan didapakan beberapa informasi adanya beberapa kendala yang dihadapi dalam peningkatan ketrampilan keuangan tersebut, karena keterbatasan anggaran sehingga cakupan penerima manfaat relatif kecil. Sehingga secara garis besar program-program ini relatif kurang dalam meningkatkan kompetitifness SDM di Kota Kediri.

4) Pengalaman Internasional (International experience), yaitu Hasil Survey pengalaman para manajer senior di dunia internasional yang signifikan secara umum (International experience of senior managers is generally significan).

Pada saat ini pengalaman para manajer senior di dunia internasional yang signifikan secara umum yang dimiliki Indonesia secara umum masuk peringkat ke 29 dari 61 negara pada hasil survey IMD World Talent Ranking tahun 2015. Untuk faktor ini Pemerintah daerah relatif tidak dapat mengintervensi secara langsung.

5) Manajer senior berkompeten (Competent senior managers), yaitu Hasil Survey kesiapan pemanfaatan Manajer senior berkompeten (Competent senior managers are readily available).

Pada saat ini kesiapan pemanfaatan Manajer senior berkompeten yang dimiliki Indonesia secara umum masuk peringkat ke 38 dari 61 negara pada hasil survey IMD World Talent Ranking tahun 2015. Untuk faktor ini Pemerintah daerah relatif tidak dapat mengintervensi secara langsung, namun pemerintah daerah dapat mendorong peningkatan faktor ini melalui suporting dan fasilitasi kegiatan pelatihan kewirausahaan dan investasi, sehingga dapat meningkatkan jumlah wirausaha/manajer yang kompeten, meskipun secara kuantitas program tersebut relatif belum mampu berkontribusi secara signifikan pada peningkatan kesiapan pemanfaatan Manajer senior berkompeten yang dimiliki Indonesia.

6) Sistem Pendidikan (Educational system), yaitu Hasil Survey kesesuaian sistem pendidikan dengan kebutuhan untuk suatu kompetisi ekonomi (The educational system meets the needs of a competitive economy).

Pada saat ini pada sistem pendidikan kita sudah ada muatan pendidikan ekonomi mulai tingkat sekolah menengah pertama hingga perguruan tinggi. Baik berupa kemampuan ekonomi secara umum maupun teknis diantaranya ketrampilan akuntansi.

Sehingga saat ini hanya perlu menanamkan semangat kewirausahaan pada generasi penerus kita. Kesadaran akan datangnya masa perdagangan bebas dan semangat untuk berkompetisi perlu ditanamkan mulai tingkat sekolah menengah hingga perguruan tinggi. Disini peranan pemerintah provinsi dalam pengelolaan pendidikan menengah dan pemerintah pusat dalam pengelolaan pendidikan tinggi.

Untuk tingkat menengah atas sebenarnya sudah cukup banyak SMK yang ada namun saat ini masih berfokus pada beberapa bidang yang dianggap masih dibutuhkan lapangan pekerjaan, belum berfokus pada potensi wilayah dan kebutuhan spesifik daerah. Namun secara garis besar proramprogram tersebut relatif mendukung peningkatan kompetitiness SDM di Kota Kediri.

7) IImu Pengetahuan di Sekolah (Science in schools), yaitu Hasil Survey Kecukupan penekanan ilmu pengetahuan di sekolah (Science in schools is sufficiently emphasized).

Pada saat ini Kecukupan penekanan ilmu pengetahuan di sekolah yang dimiliki Indonesia secara umum cenderung stagnan pada penekanan ilmu pengetahuan di sekolah di Indonesia jika dibandingkan dengan negara-negara lain yang disurvey.

Hal tersebut terjadi bukan karena penelitian pengembangan dan penerapan ilmu pengetahuan di Indonesia yang menurun, tetapi lebih karena kurangnya publikasi hasil-hasil penelitian, pengembangan dan penerapan ilmu pengetahuan di sini yang kurang. Hal ini terjadi 
karena minimnya media publikasi ilmiah bertaraf nasional dan internasional yang dimiliki negara kita, sehingga relatif terbatasnya jumlah publikasinya. Sedangkan dalam hal ini karena menyangkut pendidikan tinggi, maka menjadi domain pemerintah pusat.

sedangkan pemerintah provinsi dapat mensupport media publikasi ilmiah yang dimiliki lembaga litbangnya. Untuk Pemerintah kota Kediri harus merevitalisasi dan optimalisasi supporting lembaga litbangnya dan media publikasi ilmiah yang dimilikinya. Sehingga secara garis besar besar proram-program pada indikator ini relatif kurang dapat mendukung peningkatan kompetitiness SDM di Kota Kediri.

8) Pendidikan Universitas (University education), yaitu Hasil Survey kesesuaian Pendidikan Universitas dengan kebutuhan untuk suatu kompetisi ekonomi (University education meets the needs of a competitive economy).

Sesuai dengan UU no 23 tahun 2014 untuk pendidikan Universitas atau Perguruan Tinggi ini merupakan Domain dari Pemerintah Pusat, sedangkan untuk pemerintah Kota Kediri hanya dapat mensupport dengan pengembangan infrastruktur kota untuk mendukung program tersebut, dan untuk hal tersebut pemerintah kota telah melaksanakannya. Sehingga secara garis besar besar Pemerintah Kota Kediri relatif mendukung peningkatan kompetitiness SDM sesuai domainnya.

9) Pendidikan Manajemen (Management education), yaitu Hasil Survey kesesuaian Pendidikan Manajemen dengan kebutuhan untuk suatu kompetisi ekonomi (Management education meets the needs of the business community).

Pendidikan formal manajemen dilaksanakan oleh perguruan tinggi yang merupakan domain dari pemerintah pusat, namun untuk pendidikan nonformal pemerintah daerah telah mengambil peran dengan memberikan pendidikan dan pelatihan kewirausahaan yang salah satu outputnya dengan dikeluarkannya sertifikat kompetensi, meskipun secara kuantitas belum dapat mencover kebutuhan semua anggota masyarakat. Nemun dengan kontinyuitas pelaksanaan program ini akan relatif mendukung peningkatan kompetitiness SDM di Kota Kediri.

10) Ketrampilan Bahasa (Language skills), yaitu Hasil Survey kesesuaian Ketrampilan Bahasa dengan kebutuhan untuk perusahaan (Language skills meet the needs of enterprises).

Pada saat ini kesesuaian Ketrampilan Bahasa dengan kebutuhan untuk perusahaan yang dimiliki Indonesia berada di bawah Singapura (7), Filipina (18) dan malaysia (20).

Saat ini modal bahasa Inggris tersebut sudah diberikan pada pendidikan formal sejak Pendidikan Dasar, bahkan dibanyak tempat sudah mulai diberikan sejak TK, bahkan Pra TK. Pada pendidikan nonformal banyak berdiri lembaga-lembaga bimbingan pendidikan bahasa asing, dimana yang paling banyak adalah lembaga pendidikan atau pelatihan bahasa Inggris. Berbagai pola dan metode pendidikan/pelatihan bahasa telah dikembangkan untuk meningkatkan kapasitas dan kecepatan penguasaan bahasa Inggris. Bahkan dibeberapa wilayah sudah dicanangkan sebagai "Kampung Inggris", dimana ada kewajiban dan pembiasaan penggunaan bahasa Inggris dalam setiap kegiatan komunikasi sehari-hari.

Pemerintah Kota Kediri sendiri mencanangkan program "English Massive Program (EMAS)" oleh Dinas Pendidikan. Pelatihan bahasa inggris berbasis massa yang dilaksanakan secara gratis. Masyarakat secara gratis akan mendapatkan pelatihan bahasa inggris di tingkat RT dengan asisten tutor terpilih yang telah dibina secara khusus dibawah Dinas Pendidikan Kota Kediri. Tahun 2015 pada tahap pelatihan Tutor sedangkan tahun 2016 diprogramkan untuk implementasi English Massie di seluruh RT di wilayah Kota Kediri. Sehingga jika dilaksanakan secara konsisten program ini akan relatif mendukung peningkatan kompetitiness SDM di Kota Kediri. 
11) Mobilitas Ikatan Pelajar (Student mobility inbound), yaitu perseribu siswa asing pada sekolah menengah tingkat atas (Foreign tertiary-level students per 1,000 inhabitants).

Program terkait pelajar asing pada kegiatan pertukaran pelajar merupakan domain dari Pemerintah Pusat.

12) Kajian Pendidikan (Educational assessment - PISA), yaitu hasil kajian PISA terhadap pendidikan pada penduduk usia 15 tahun keatas (PISA survey of 15-year-olds).

Kajian pendidikan oleh PISA bertujuan untuk mengukur prestasi literasi membaca, matemetika dan sains siswa sekolah berusia 15 tahun di negara-negara peserta. Pada saat ini hasil kajian PISA terhadap pendidikan pada penduduk usia 15 tahun keatas di Indonesia secara umum masuk peringkat ke 54 dari 61 negara pada hasil survey IMD World Talent Ranking tahun 2015, berada di bawah Singapura (2), Thailand (44) dan malaysia (47).

Untuk meningkatkan prestasi literasi membaca, matemetika dan sains siswa sekolah berusia 15 tahun diperlukan diperlukan penyesuaian kurikulum pada tingkat pendidikan dasar. Pada UU No.23 tahun 2014 pada pembagian tugas dan wewenang hal ini menjadi domain pemerintah pusat. Namun pada pengelolaan pendidikan dasar menjadi domain Pemerintah kabupaten/kota. Dan untuk itu pemerintah Kota telah meluncurkan beberapa program untuk meningkatkan kualitas pendidikan masyarakat Kota, khususnya untuk anak-anak di bawah usia 15 tahun. Diantaranya pemenuhan buku-buku sekolah, baik wajib maupun suplemen, angkutan gratis untuk anak sekolah, seragam gratis dan lain-lain. Sehingga hal ini diharapkan mampu memotivasi semangat belajar anak dan meringankan beban masyarakat. Dan jika dilaksanakan secara konsisten program ini akan relatif mendukung peningkatan kompetitiness SDM di Kota Kediri.

\section{KESIMPULAN}

Berdasarkan hasil analisa data penelitian diatas dapat ditarik kesimpulan, antara lain:

1. Kebijakan Pemerintah daerah dalam meningkatkan Daya Saing Sumber Daya Manusia (SDM) Kota Kediri di dunia internasional relatif banyak, beragam dan dilaksanakan oleh banyak SKPD yang dimiliki baik Pemerintah Provinsi maupun Pemerintah Kota.

2. Secara rerata kebijakan-kebijakan Pemerintah daerah di Kota Kediri tersebut akan relatif berdampak positif terhadap peningkatan Daya Saing Sumber Daya Manusia (SDM) di dunia internasional.

\section{SARAN}

Berdasarkan hasil analisa data penelitian dan kesimpulan diatas ada beberapa hal yang harus dilakukan untuk memperbaiki, antara lain:

1. Pemerintah Kabupaten/Kota perlu untuk update secara berkala dan kontinyu data tenaga kerja beserta potensi yang dimilikinya sehingga dapat memberikan support dan fasilitasi sesuai kebutuhan untuk pengembangan potensinya tersebut.

2. Perlu adanya integrasi dan sinkronisasi data penerima manfaat dari SKPD-SKPD pelaksana program di Kabupaten/Kota.

3. Pemerintah Kabupaten/Kota dan Provinsi perlu terus meningkatkan Sosialisasi ancaman dampak negatif MEA untuk merubah mindset dan meningkatkan motivasi masyarakat untuk terus meningkatkan daya saingnya.

4. Pemerintah Kabupaten/kota dan Provinsi juga harus merevitalisasi dan optimalisasi unit Litbangnya baik dalam riset dan pengembangan ilmu pengetahuan dan teknologi, serta supporting media publikasi yang dimilikinya 
5. Pemerintah Kabupaten/kota dan Provinsi dapat bekerjasama untuk memberikan pendidikan dan pelatihan kewirausahaan yang salah satu outputnya dengan dikeluarkannya sertifikat kompetensi.

6. Pemerintah Provinsi dapat merancangkan program kegiatan serupa dengan program EMAS Pemkot Kediri untuk diterapkan diseluruh kabupaten/kota di seluruh wilayah provinsi Jawa Timur.

\section{DAFTAR PUSTAKA}

Badan Pusat Statistika Provinsi Jawa Timur, 2014a, Laporan Eksekutif Keadaan angkatan Kerja di Jawa Timur 2013-2014, Surabaya

Badan Pusat Statistika Provinsi Jawa Timur, 2014b, Keadaan angkatan Kerja di Jawa Timur Agustus 2014, Surabaya

Badan Pusat Statistika Provinsi Jawa Timur, 2015, Jawa Timur dalam Angka 2015, Surabaya

Badan Pusat Statistika Kota Kediri, 2014a, Kota Kediri dalam angka 2014, Kediri

Badan Pusat Statistika Kota Kediri, 2015, Statistika Daerah Kota Kediri 2015, Kediri

Bris, Arturo Prof., dkk, 2014, IMD World Talent Report 2014, IMD World Competitiveness Centre, Switzerland.

Bris, Arturo Prof., dkk, 2015, IMD World Talent Report 2015, IMD World Competitiveness Centre, Switzerland.

Ngasuko, Tri Achya, 2015, Daya Saing Sumber Daya Manusia Indonesia Menghadapi Masyarakat Ekonomi ASEAN,Kementerian Keuangan. Jakarta

Schwab, Klaus Prof., dkk, 2015, The Global Competitiveness Report 2015-2016, The World Economic Forum, Switzerland.

UNDP, 2015, Human Development Report 2015; Work for human development.

Ulfie Eriza, 2014, Analisa Kesenjangan Pendapatan antar Kabupaten/Kota di Provinsi Jawa Timur di Era Desentralisasi Fiskal, Fakultas Ekonomi dan Bisnis Universitas Brawijaya Malang Jurusan Ilmu Ekonomi, Malang

\section{DARI INTERNET}

https://www.bps.go.id/Brs/view/id/1196 yang diunduh tanggal 11-04-2016 pukul 10.45 WIB.

(http://www.adakitanews.com/jumlah-pengangguran-di-kota-kediri-capai-766/, Senin, 28-09-2015).

\section{REGULASI}

Undang-undang Republik Indonesia Nomor 38 Tahun 2008 tentang Pengesahan Charter of Association of Southeast Asian Nation (Piagam Perhimpunan Bangsa-bangsa Asia Tenggara).

Undang-undang Republik Indonesia Nomor 23 Tahun 2014 tentang Pemerintahan Daerah

SK Gubernur Jawa Timur Nomor 188/263/KPTS/ 013/2004; 188/286/KPTS/ 013/2005; 188/318/KPTS/ 013/2006; 188/403/KPTS/ 013/2008 Tentang Penetapan Upah Minimum Kabupaten/Kota Di Jawa Timur Tahun 2005-2009.

Peraturan Gubernur Jawa Timur Nomor 68/2009; 93 /2010; 81/2011; 72/2012; 78/2013; 72/2014; 68 Tahun 2015 Tentang Upah Minimum Kabupaten/Kota Di Jawa Timur Tahun 2010-2016 